\title{
MENTORING CHILDREN WITH LEARNING DIFFICULTIES IN INCLUSIVE PRIMARY SCHOOLS
}

\author{
Nursaptini \\ Pendidikan Guru Sekolah Dasar, Fakultas Keguruan dan Ilmu Pendidikan, Universitas Mataram \\ nursaptini@unram.ac.id
}

\begin{abstract}
Muhammad Sobri, Setiani Novitasari, Dyah Indraswati, Deni Sutisna
Pendidikan Guru Sekolah Dasar, Fakultas Keguruan dan Ilmu Pendidikan, Universitas Mataram muhammad.sobri@unram.ac.id, setianinovitasari@unram,ac.id,dyahindraswati@unram.ac.id, denisutisna@unram.ac.id
\end{abstract}

\section{Claver Nzobonimpa (Coresponding Author) \\ Socio-Antropology, University of Burundi \\ nzobonimpa@ub.edu.bi}

\begin{abstract}
Abstrak:
Penelitian ini bertujuan untuk mengetahui proses pembelajaran bagi anak kesulitan belajar pada sekolah inklusi di Sekolah Dasar. Penelitian ini merupakan penelitian kualitatif dengan pendekatan studi-kasus. Penelitian dilaksanakan di SDN 1 Sangkawana Kecamatan Batukliang Kabupaten Lombok Tengah. Subyek dalam Penelitian ini adalah Kepala Sekolah, Guru kelas rendah. Pengumpulan data melalui observasi non partisipan, wawancara semi terstruktur dan dokumentasi. Analisis data dilakukan dengan menggunakan model Spiral Analisis yang dikembangkan Creswell. Hasil Penelitian bahwa kompetensi guru dalam pelayanan anak kesulitan belajar sangat perlu dimiliki. Guru merupakan penentu keberhasilan proses pembelajaran terutama bagi anak kesulitan belajar yang membutuhkan bimbingan lebih dalam belajar. Pada umumnya proses pembelajaran bagi anak kesulitan belajar di sekolah inklusi sama dengan sekolah reguler. Perbedaanya adalah dalam pemberian aktivitas pembelajaran dan pelayanan yang lebih dalam bentuk remedial. Hal ini dilakukan dimulai dari guru melakukan adaptasi dalam merancang Rencana Pelaksanaan Pembelajaran sesuai dengan keadaan siswa
\end{abstract}

Kata Kunci: Pendampingan, Kesulitan Belajar, Sekolah Inklusi

\begin{abstract}
:
This study aims to determine the learning process for children learning difficulties in inclusive schools in elementary schools. This research is qualitative research with a case-study approach. The study was conducted at SDN 1 Sangkawana Batukliang District, Central Lombok Regency. Subjects in this study were the Principal, Low grade teacher Data collection through non-participant observation, semi-structured interviews and documentation. Data analysis was performed using the Spiral Analysis model developed by Creswell. Research Findings that teacher competencies in the service of children with learning difficulties need to be possessed. The teacher is a determinant of the success of the learning process especially for children with learning difficulties who need more guidance in learning. In general, the learning
\end{abstract}


process for children with learning difficulties in inclusive schools is the same as regular schools. The difference is in the provision of learning activities and services that are more remedial. This is done starting from the teacher doing adaptation in designing the Learning Implementation lesson plan by the circumstances of the students

Keywords: Mentoring, Learning Difficulties, Inclusion Schools

\section{INTRODUCTION}

Inclusive education is one solution so that all children get the rights and the best education services. Inclusive education based on the Republic of Indonesia's Minister of National Education Regulation No. 70 of 2009 is an education administration system that provides opportunities for all students who have disabilities and have special intelligence and talent potential to attend education or learning in an educational environment together with students in general.

Inclusive education provides educational services for children with special needs in regular classes closest to where they live. It is expected that students can understand the differences and do not occur discrimination (Darma \& Rusyidi, 2015). In addition to maximizing the opportunity for children to engage in normal activities (Saputra, 2016).

In order to achieve the goal of inclusive education, teachers in primary schools must be prepared (Woodcock, 2013). In providing the best service and developing the potential of students. All teachers need to be trained and prepared in serving students with special needs in regular classes (Adedoyin \& Okere, 2017). This can begin with the teacher's ability to identify the possibility of children with special needs. This ability will be a capital for a teacher in providing further education programs and services.

Every child has the potential to experience problems in learning, but there are problems that are mild and do not require special attention from others, and there are also those with severe learning problems that need attention and assistance from others (Awwad, 2015). One of them is children who have difficulty learning to need special services in learning. As the results of a preliminary study at SDN 1 Sangkawana that in the school there were cases of children learning difficulties. 
Children with learning difficulties are children who have difficulty in carrying out academic tasks at school so that learning achievement is below the true potential (Aristiani, 2013). Children learning difficulties can be identified through low learning outcomes, slow in doing learning tasks, unable to capture material explanations (Ummah, 2018). Weaknesses of students who have difficulty learning are in basic reading skills, difficulty understanding text (Taymans \& Kosaraju, 2012). The term learning difficulties refers to various disorders that involve special challenges such as reading, writing, listening, speaking, concentrating, and solving mathematical problems (Parks, 2010). Children also have difficulty starting assignments (Akhutina, Tatiana A. \& Pylaeva, 2012).

The implementation of learning in inclusive schools requires teachers who have competence in serving students with special needs. But in practice there are still many teachers who do not yet have these competencies. For this reason, it is necessary to study the learning process for children with learning difficulties in inclusive schools in primary schools.

\section{METHODS}

This research is a qualitative research with a case-study approach. This approach is used to explore data that involves various sources of information. Researchers revealed that the phenomenon of particular concern in this study was the learning process for children with learning difficulties in inclusive schools in primary schools.

Research settings at SDN 1 Sangkawana Batukliang District, Central Lombok Regency. The choice of location is based on the consideration that SDN 1 Sangkawana is one of the schools designated as an inclusive education provider school. The subjects in this study were the Principal, Teachers grades 1, 2 and 3. The research subjects were determined by Purposive Sampling.

Sources of data taken from secondary data and primary data obtained through direct interaction, while secondary data obtained from documents related to research problems. Then, the techniques and instruments of data collection through 1) non-participant observation. 2) semi-structured interviews and 3) documentation.

Data analysis was performed by adapting the Spiral Analysis model developed by Creswell, namely organizing data, reading and making memos, describing, classifying, and interpreting data, presenting data and visualizing data 


\section{RESULTS AND DISCUSSION}

Many children with special needs are not diagnosed and seen with the eye. Children with special needs include those who have learning, speaking, physical, cognitive, auditory, sensory and emotional difficulties. This child is more likely than other children to be out of school, or out of school or in and out of school (Purnomo, 2016). Therefore, identification of students' needs in learning is needed.

Based on the results of researchers' interviews with Sangkawana Elementary School 1 teacher that "identification of the state of students starts from the beginning of learning. This was only done because the school was designated as a new inclusive school this academic year.

This statement is reinforced by the results of interviews with the principle:

SDN 1 Sangkawana was appointed as an inclusive school in this school year thanks to the collaboration between the Central Lombok district education office and FKIP Mataram University.

The appointment of SDN 1 Sangkawana as an inclusive school gives a new color in the learning process. This is because before the appointment of this school as an inclusive school the learning process took place equally there was no more service for students learning difficulties. After there is an inclusion program the school provides services for students learning difficulties. As one teacher explained at the low - grade level that:

With the appointment of this elementary school as an inclusive school. We get training so we get knowledge on how to handle students with special needs. For this year we only handle students learning difficulties there are no other children with special needs.

Teachers are required to have knowledge and skills in service to children with special needs. To be able to provide quality educational services according to the needs and abilities of students. Therefore, teachers need professional improvement and pedagogical competence in carrying out tasks (Purnomo, 2016). Teachers must have resources in classroom management and direct experience in handling children's learning difficulties (Donohue \& Bornman, 2015).

Early identification of student needs is very necessary in order to get special services. This early detection can be through basic skills such as disturbances in the process of learning colors or letters and has basic mathematical facts (Budiyanto, 2017). This is not much different from the results of an interview with one of the teachers:

The criteria for children with learning difficulties are not wanting to do anything, just sitting, copying the writing on the board to the book, also not wanting to let alone recite letters and numbers 
When a teacher knows the special needs that his students have, it will be easier to develop lesson plans. As a result of Brueggemann's research (2014) that when an educator knows that he will teach children who have learning difficulties. Then they will access ideas that have successfully served students who have learning difficulties (Brueggemann, 2014).

In the learning process, the teacher uses the same curriculum. But in certain teaching materials carried out some simplifications or modified according to the needs and abilities or potential of students (Wahyudi \& Kristiawati, 2016). The main principle in the modification is to look at the characteristics and needs of students so that appropriate modification results can be found. Adjustment of learning activities with the potential of students in conducting activities will help students to be able to complete these activities (Asiyah, 2018).

One example in learning activities, students who have difficulty learning in their is practice simplified. Students with learning difficulties are asked to name only core family members while for students who do not have special needs more complex.

The success standards used by teachers in learning in inclusive schools are the same but differ in quality. Implementation of assessment uses a different method from public schools. The difference is that in public schools, it is enough to take grades with a single question test, for example, the semester 1 exam and the grade promotion test, but for inclusive schools, it requires several grades to be taken.

Teacher skills in the learning process are very necessary. In the learning process at SDN 1 Sangkawana, teachers use remedial therapy. Remedial therapy is direct guidance by the teacher according to the type of learning difficulties faced by children (Suryani, 2010). The teacher repeatedly explains material that is not understood by students.

Then based on observations at SDN 1 Sangkawana it was found that in the learning process with different characteristics of children. The seating arrangement of children in the classroom by the teacher is deliberately told to sit with regular students who are smarter. This can help them in lessons that are rather difficult for children to understand. Various things are done in the learning process. So that there is a change in the quality of students and after the teacher gets knowledge about how to serve students with learning difficulties. There has been a change as explained by the coordinator of the implementation of the inclusive school who is also a class teacher that "there is a change after there is a handling of children such as in-class 1 children want to write". 


\section{CONCLUSION}

The learning process for children with learning difficulties in inclusive schools is the same as children who do not have special needs. The difference is in the provision of learning activities, and more remedial services. Teachers have a very important role in the implementation of inclusive schools. Competence regarding the handling of children's services with learning difficulties is essential. Before becoming an inclusive school students who had difficulty learning at SDN 1 Sangkawana did not get more services. However, after becoming an inclusive school, teachers receive training so that children with learning difficulties change their quality.

\section{SUGGESTION}

Based on the above conclusions, several suggestions can be given including:

1. In the mentoring process for children with learning difficulties, the quality of their mentoring needs to be improved.

2. There needs to be training for accompanying teachers in order to add mentoring skills to children with learning difficulties.

\section{REFERENCES}

Adedoyin, O., \& Okere, E. (2017). The Significance of Inclusion Concept in the Educational System as Perceived by Junior Secondary School Teachers: Implications for Teacher Training Programmes in Botswana. Global Journal of Social Sciences Studies, 3(1), 13-28. https://doi.org/10.20448/807.3.1.13.28

Akhutina, Tatiana A. \& Pylaeva, N. M. (2012). Overcoming Learning Disabilities. New York: Cambridge University Press.

Aristiani, N. (2013). Penggunaan Media Batang Napier dalam Meningkatkan Kemampuan Operasi Perkalian Bagi Anak Kesulitan Belajar Kelas 3 SD 11 Belakang Tangsi Padang. Jurnal Ilmiah Pendidikan Khusus, 1(1), 294-310. Retrieved from http://ejournal.unp.ac.id/index.php/jupekhu

Asiyah, D. (2018). Dampak Pola Pembelajaran Sekolah Inklusi terhadap Anak Berkebutuhan Khusus. $\quad$ Prophetic, 1(01), 69-82. $\quad$ Retrieved from http://www.syekhnurjati.ac.id/jurnal/index.php/prophetic/article/view/3480

Awwad, M. (2015). Urgensi Layanan Bimbingan dan Konseling Bagi Anak Berkebutuhan Khusus. Al-Tazkiah: Jurnal Bimbingan Dan Konseling Islam, 4(1), 46-64. Retrieved from https://journal.uinmataram.ac.id/index.php/altazkiah/article/view/76

Brueggemann, T. A. E. (2014). Diagnostic Assessment of Learning Disabilities in Childhood 
Bridging the Gap Between Research and Practice. New York: Springer.

Budiyanto. (2017). Pengantar Pendidikan Inklusif Berbasis Budaya Lokal (1st ed.). Jakarta: Prenadamedia Group.

Darma, I. P., \& Rusyidi, B. (2015). Pelaksanaan Sekolah Inklusi Di Indonesia. Prosiding Penelitian Dan Pengabdian Kepada Masyarakat, 2(2), 223-227. https://doi.org/10.24198/jppm.v2i2.13530

Donohue, D. K., \& Bornman, J. (2015). South African Teachers' Attitudes toward the Inclusion of Learners with Different Abilities in Mainstream Classrooms. International Journal of Disability, Development and Education, 62(1), 42-59. https://doi.org/10.1080/1034912X.2014.985638

Parks, P. J. (2010). Learning disabilities Diseases and Disorders. San Diego: ReferencePoint Press.

Purnomo, E. (2016). Kebutuhan Guru Sekolah Dasar Inklusi Dalam Meningkatkan Kompetensi Melalui Media Video. Jurnal Kwangsan, 4(2), 95. https://doi.org/10.31800/jurnalkwangsan.v4i2.88

Suryani, Y. E. (2010). Kesulitan belajar. Magistra, (73), 33-47.

Taymans, J. M., \& Kosaraju, S. (2012). Introduction to the Journal of Learning Disabilities Special Issue: Adults With Learning Disabilities in Adult Education. Journal of Learning Disabilities, 45(1), 3-4.

Ummah, D. M. (2018). Analisis Kesulitan Belajar pada Anak Berkebutuhan Khusus (ABK) Di SMA Negeri 10 Kota Ternate. Jurnal Bimbingan Dan Konseling Terapan, 2(1), 32-40. https://doi.org/10.30598/jbkt.v2i1.233

Wahyudi, W., \& Kristiawati, R. (2016). Gambaran Sekolah Inklusif di Indonesia: Tinjauan Sekolah Menengah Pertama. In Gambaran Sekolah Inklusif Di Indonesia. Retrieved from http://publikasi.data.kemdikbud.go.id/uploadDir/isi_14D0F106-F4EE-486B-A74F84A191B4AD25_.pdf

Woodcock, S. (2013). Trainee teachers' attitudes towards students with specific learning disabilities. Australian Journal of Teacher Education, 38(8), 16-29. https://doi.org/10.14221/ajte.2013v38n8.6 